\title{
Theorizing Russian model of the digital divide ${ }^{1}$
}

\author{
Elena Vartanova ${ }^{2}$ \\ Anna Gladkova \\ Daniil Lapin \\ Elina Samorodova \\ Olga Vikhrova
}

Lomonosov Moscow State University, Russia

To cite this article: Vartanova, E., Gladkova, A., Lapin, D., Samorodova, E., \& Vikhrova, O. (2021). Theorizing Russian model of the digital divide. World of Media. Journal of Russian Media and Journalism Studies 1. DOI: 10.30547/worldofmedia.1.2021.1

\begin{abstract}
The paper approaches digital divide as a complex multi-dimensional and multi-level problem, not being limited to the Internet access only. We argue that regardless of some universal trends previously identified by scholars, every country retains its national specifics in ICT access, skills and benefits people can get from using ICTs. In this vein, we theorize Russian model of the digital divide, approaching it through three main angles: state regulation of digitalization processes in Russia on federal and regional levels; different modes of the digital technology use in a cross-regional comparative perspective; and specific mechanisms for the analysis and further overcoming digital divide in Russia. For the latter point, we propose a 'digital passport' of the Russian regions that allows for better understanding of the digitalization progress in particular regions of the country and for more efficient policy-making on site. Lastly, we test a 'digital passport' model on eight federal subjects of Russia to show its applicability of the study of the digital divide in different regional contexts.
\end{abstract}

\section{Keywords}

Digital divide, digital passport, Russia, media, ICTs, digital literacy, regulation.

${ }^{1}$ The reported study was funded by RFBR and EISR, project number 20-011-31329.

${ }^{2}$ Corresponding author:

Elena Vartanova, Lomonosov Moscow State University, Faculty of Journalism, 9, Mokhovaya st, Moscow, Russia.

Email: eva@smi.msu.ru 


\section{Introduction}

The continuing and ever deepening social injustice, reflected in a high number of global, social and individual inequalities in the digital society, has become one of the most widely debated problems in media and communication studies worldwide (van Dijk, \& Hacker, 2003; Ragnedda, \& Muschert, 2013). The digital divide itself has been often considered a global problem, consisting in unequal access and the consequent unequal use of digital technologies, with special attention given to benefits of easy access to digital technologies and consequences of digital deprivation (van Deursen, \& Helsper, 2015).

For a long time, discussions over digital inequalities have been framed mostly around the digital divide. The studies focused on the degree of access to computer technologies and Internet, and examined computer literacy, basing on abilities to use Email, search for information online, download music, etc (van Dijk, \& Hacker, 2003). However, the introduction and widespread use of machine learning and artificial intelligence in different decision-making processes, related to citizens' life (health, justice, policing), shifted the research on digital divide (Hargittai, 2002; van Deursen, \& van Dijk, 2014, 2018). Reason for that being more complex issues, arising from the inequalities and concerning aspects of how digital technologies work and what influence they could have (Carmi, \& Yates, 2020). In this context, much has been written on digital inclusion of various social groups: children and young people (Livingstone, \& Helsper, 2010), disabled people (Goggin, Ellis, \& Hawkins, 2019), elderly people (van Deursen, \& Helsper, 2015) and others. Furthermore, research has been made on theorizing and measuring digital capital (Ragnedda, Ruiu, \& Addeo, 2019; Gladkova, Vartanova, \& Ragnedda, 2020), 'a bridge capital between offline and online life chances' (Ragnedda, 2018), which is becoming increasingly important in digital reality of today.

The problem of digital divide in different national contexts has been thoroughly analyzed by researchers across the world (Chipeva, et al. 2018). However, little attention has been given to the problem of digital inequalities in Russia, specifically from an interregional perspective. This appears surprising given that Russian Federation is a unique example of a multiethnic and multicultural nation that can hardly be found elsewhere in the world, with a total population of 146 million people, including over 190 ethnic groups speaking more than 170 languages (most recent data provided by the all-Russia census in 2010). Moreover, it is the largest country in the world, spanning over 11 time zones and covering over 17100000 square km. Russia consists of eight federal districts divided into 85 federal subjects, 22 out of which are national republics within Russia (ibid). Peculiar character of Russian society is also reflected in the way federal districts - 
while being parts of the same country - differ from each other geographically (e.g. territorial differences, distance from the large cities and the two main megapolises, Moscow and St. Petersburg, etc.), economically (e.g. average salaries rate, GDP, size and efficiency of economy, etc.), technologically (poorly developed lines of communication, including both transport connection and ICT infrastructures, first and foremost due to the sheer size of the country), socially (population density, size of urban/rural population, differences in education, employment opportunities in the labor market, etc.), as well as ethnically and linguistically (e.g. the number of smaller ethnic and cultural groups residing in particular districts of Russia) (Gladkova, \& Ragnedda, 2020).

Cross-regional varieties and contrasts become evident through the analysis of inequalities in Russia. Previous research on Russia showed that due to its complex and immense territory, economic and cultural development, historical traditions, professional journalistic practices, policy measures, legislation, uneven economic developments of the regions, geographical and climatic conditions (Vartanova, 2018), Russia represents an interesting case for the analysis of different kinds of inequalities. This topic has, indeed, attracted the attention of numerous scholars that, over the years, have focused on inequalities in socioeconomic development of Russian regions (Kolomak, 2010); in access to the higher education (Mikheeva, 2004); and in the quality of life in Russia (Bobkov, Gulyugina, \& Odintsova, 2009).

Less research, however, exists on the development of digital inequalities in Russia (Deviatko, 2013; Volchenko, 2016). So far, most publications on the digital divide in Russia (Vartanova, 2018; Volchenko, 2016; Bykov, \& Hall, 2011; Deviatko, 2013) have remained rather generic and limited to discussing digital inequalities in regard to digital economy and/or information society issues in transitional post-socialist context, aiming to conceptualize the notion of digital divide and classify theoretical approaches: from mere access problem to a deeper social issue (Vartanova, \& Gladkova, 2019). The majority of papers on digital divide in Russia approach the problem from a technological point of view, i.e. examine the divide between those included and those excluded from the digital world and analyze a multitude of factors that might influence the divide. A number of studies addressed the phenomenon of the digital divide in Russia by discussing the three levels of the digital divide (difference in access to the Internet and ICTs; differences in skills and use of ICTs; difference in benefits people gain from using internet technologies) in a comparative and interregional perspective (Gladkova, \& Ragnedda, 2020).

In this paper, we discuss the unique Russian model of digital divide, approaching it from three main angles: digital literacy and media literacy in a cross-regional 
comparative perspective; state regulation of digitalization processes in Russia on federal and regional levels; and specific mechanisms for the analysis and further resolution of the problem of digital divide. For the latter point, we propose a 'digital passport' of the Russian regions that allows for better understanding of the digitalization progress in particular regions of the country. The study explores digital divide in eight federal subjects of the Russian Federation (Moscow, Republic of Crimea, Primorsky Krai, Altai Krai, Kaliningrad Region, Republic of Tatarstan, Republic of Sakha (Yakutia), Republic of Dagestan) but we argue that the methods and the approach employed in the present research can be used for the analysis of similar processes in other regions of Russia as well.

\section{State regulation. Overcoming digital divide in national and municipal programs}

Despite the obvious advantages of digitalization, the process entails a number of problems and contradictions, and the digital divide is central among them (Vartanova, \& Gladkova, 2019). Measures to bridge the digital gap are determined by the governments on the basis of priorities and characteristics of federal and regional policies, as well as subject to the economic conditions of the constituent entities of the Russian Federation. In 2008 the Strategy for the Development of the Information Society in the Russian Federation was adopted at the state level in Russia, providing the basis for further legislative regulation of the problem of the digital divide in the country. Thereafter, in 2010, the Government of the Russian Federation signed Order No. 1815-r 'On the State Program of the Russian Federation 'Information Society (2010-2020)'. Finally, the federal law 'On Communications', which came into force in 2014, set the task to eliminate digital divide between urban residents and rural populations by creating access points in settlements with a population of 250 to 500 people.

The 'Information Technology Industry Development Strategy in the Russian Federation for 2014-2020 and for the future until 2025' set the goal to improve information technology literacy of the population. In 2017, the President of the Russian Federation signed a decree approving the second 'Strategy for the Development of the Information Society in Russia for 2017-2030', which also included the creation of a level playing field for the use of digital information technologies by the Russian citizens. The government was instructed to ensure the right of the Russian citizens to access information in the new digital environment.

Generally, it is very difficult to assess the results of the implementation of the federal strategies at the federal subject level, based on statistical data, which are sometimes not only difficult and disaggregated but also contradictory. However, 
now each of the federal subjects is implementing its own program, focused on a comprehensive or phased approach to the solution of the most pressing issues of digital divide in the region. (See Table 1).

For subsequent frequency/content analysis, a sample of regional programs of the subjects of the Russian Federation was formed on the basis of the Order of the Ministry of Finance No. 1032 dd. November 11, 2019 'On approval of lists of the entities of the Russian Federation in accordance with the provisions of paragraph 5 of Article 130 of the Budget Code of the Russian Federation'.

Entities:

- Moscow and the Republic of Tatarstan (not subsidized in 2020);

- Kaliningrad region (the share of subsidies does not exceed $10 \%$ of own revenues of the consolidated budget of the entity during two of last three reporting financial years);

- the Republics of Sakha (Yakutia) and Crimea ${ }^{3}$ (the share of subsidies exceeds $10 \%$ of own revenues of the consolidated budget of the entity during two of last three reporting financial years);

- Primorsky Krai (the share of subsidies does not exceed $20 \%$ of own revenues of the consolidated budget of the entity during two of last three reporting financial years);

- the Republics of Altai and Dagestan (the share of state subsidies exceeds $40 \%$ of own revenues of the consolidated budget of the entity during two of last three reporting financial years).

The main criterion for the inclusion of these particular federal subjects into the sample was a significantly different level of economic development. The level was determined using the Order of the Ministry of Finance No. 1032 dd. November 11, 2019 'On the approval of the lists of the subjects of the Russian Federation in accordance with the provisions of Article 130 of the Russian Budget Code'. It should be noted here that Moscow and the Republic of Tatarstan were not subsidized in 2020. In Kaliningrad region the share of subsidies from the federal budget does not exceed $10 \%$ of the amount of the consolidated budget of the subject during two of the last three reporting financial years. In the Republic of Sakha (Yakutia) and the Republic of Crimea the share of subsidies from the federal budget exceeds $10 \%$ of the amount of the consolidated budget of the subject. In Primorsky Krai the share of subsidies from the federal budget does not exceed $20 \%$ of the amount of the consolidated budget of the subject. Finally, in Altai Krai and the Republic of Dagestan the share of subsidies from the federal budget exceeds $40 \%$ of their own income.

\footnotetext{
${ }^{3}$ With the exception of Sevastopol.
} 


\begin{tabular}{|c|c|c|c|}
\hline 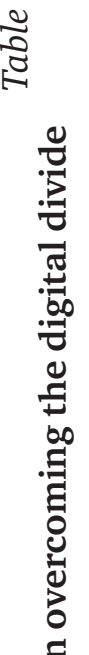 & $\begin{array}{l}\frac{y}{\tilde{y}} \\
\frac{\pi}{\pi}\end{array}$ & 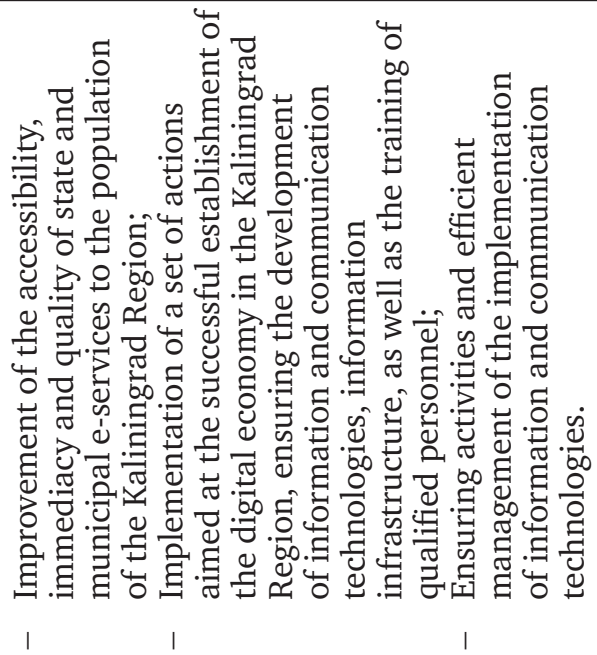 & 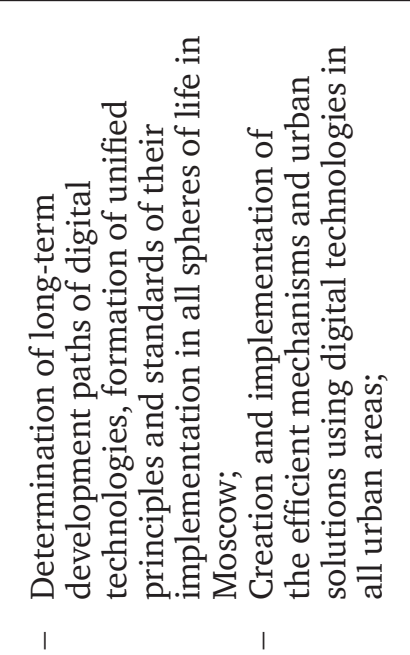 \\
\hline 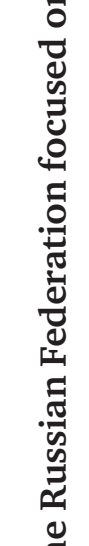 & $\begin{array}{l}\text { जै } \\
\text { đू }\end{array}$ & 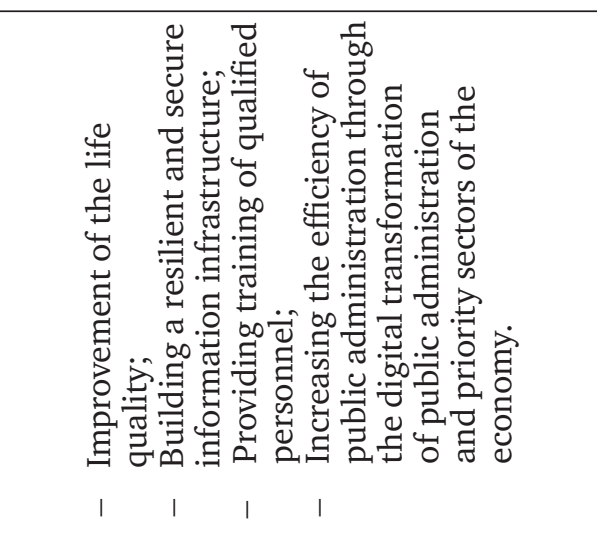 & 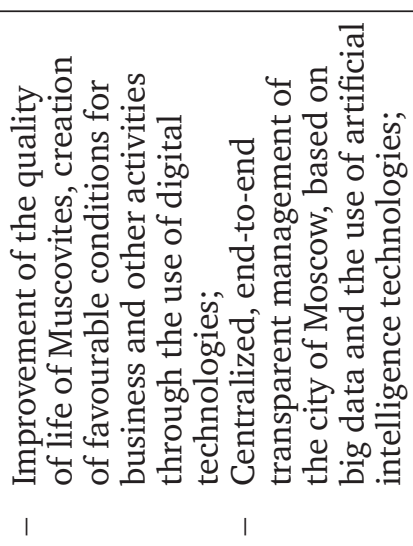 \\
\hline 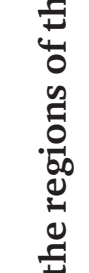 & 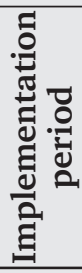 & 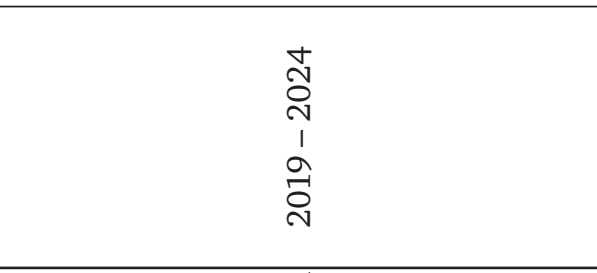 & 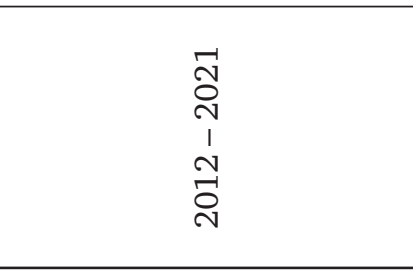 \\
\hline 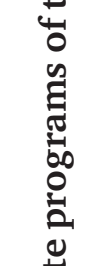 & 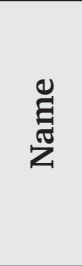 & 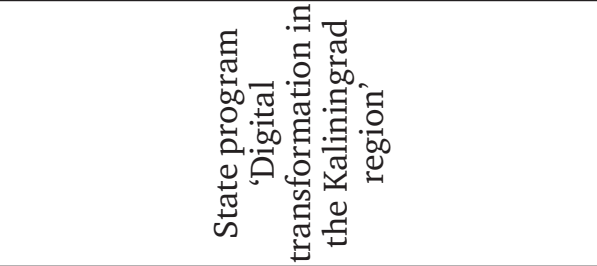 & 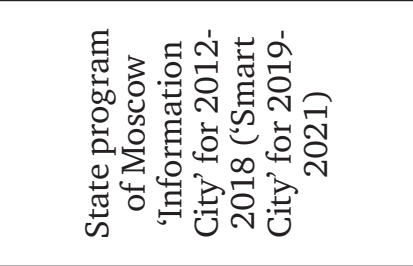 \\
\hline & 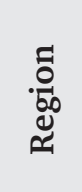 & 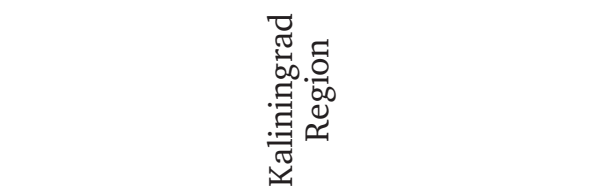 & 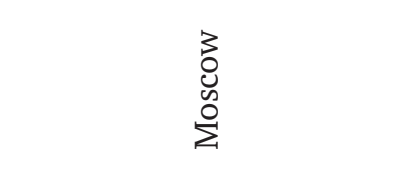 \\
\hline
\end{tabular}




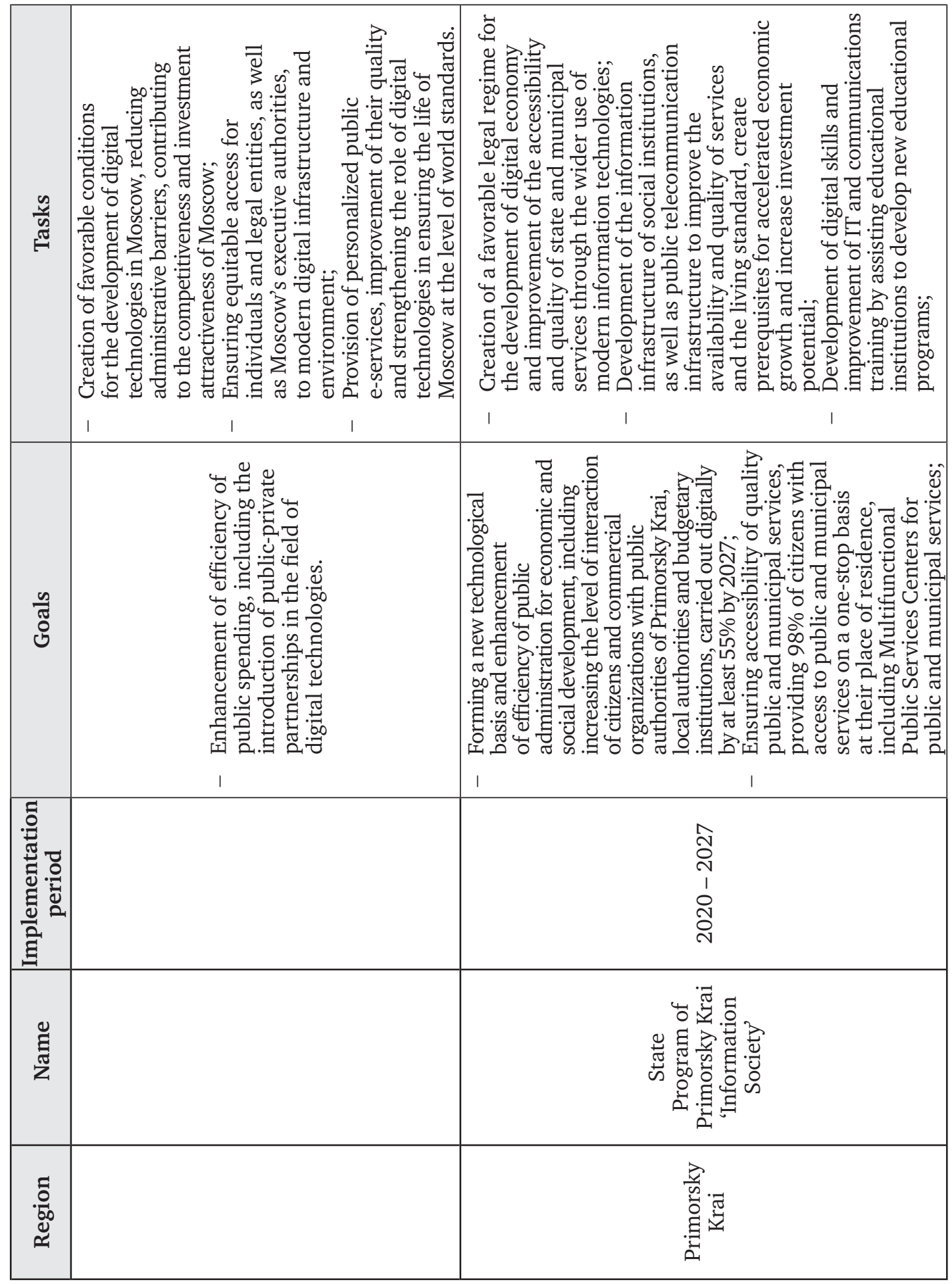




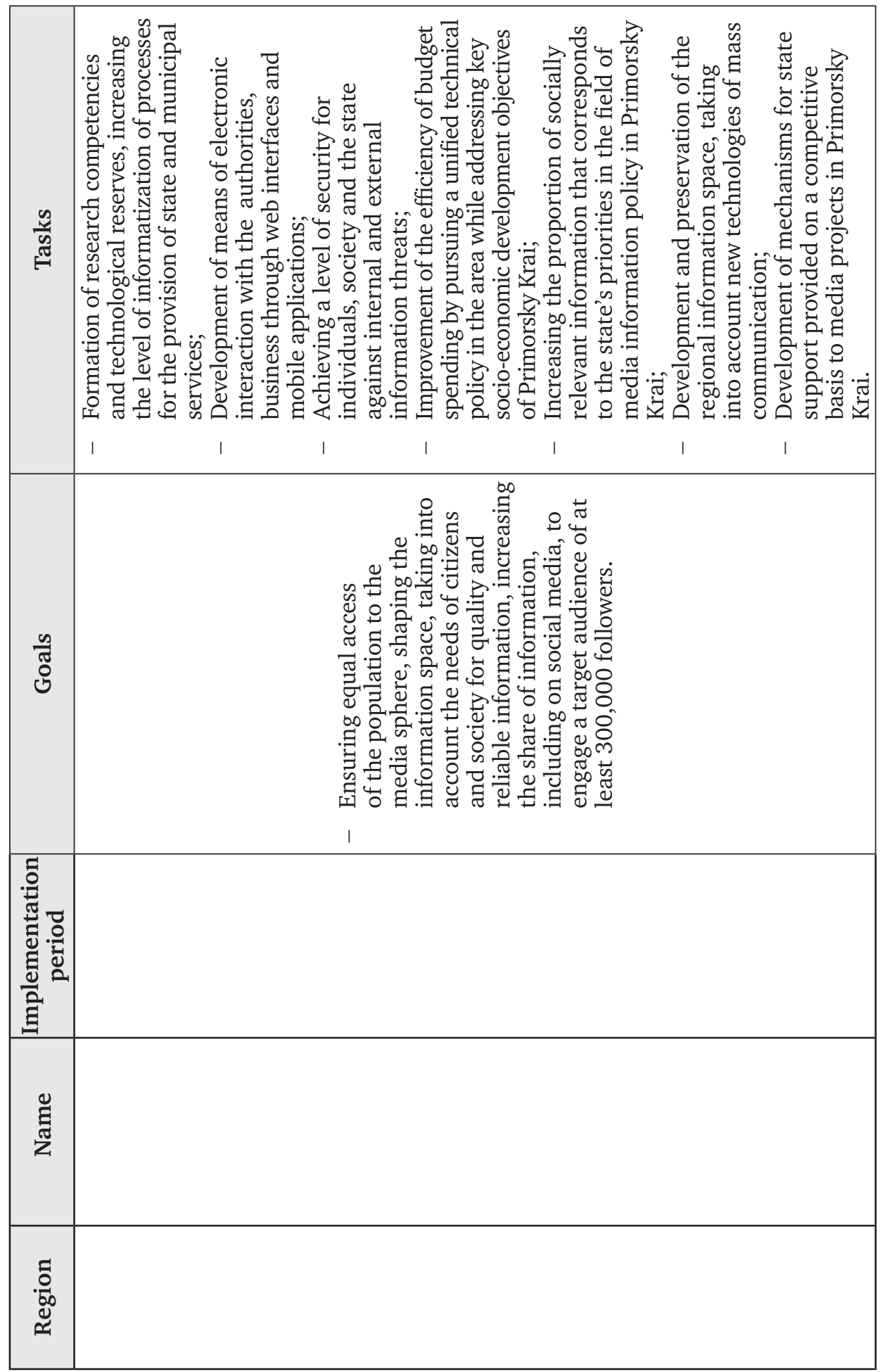




\begin{tabular}{|c|c|c|}
\hline 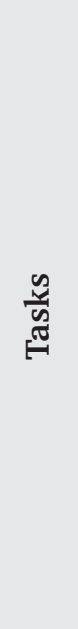 & 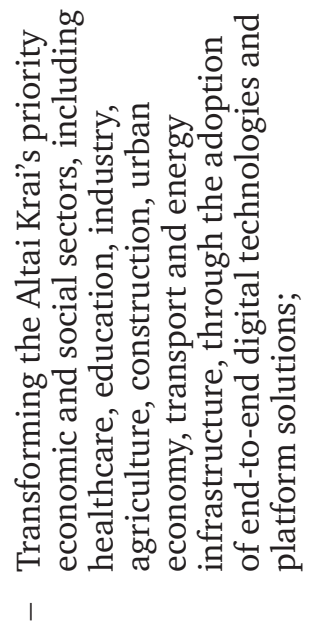 & 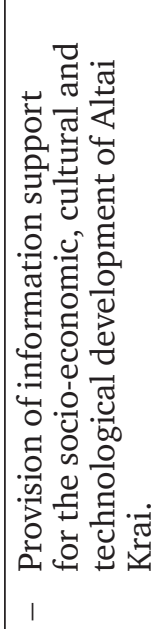 \\
\hline 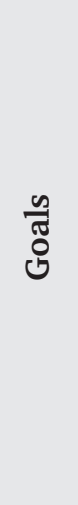 & 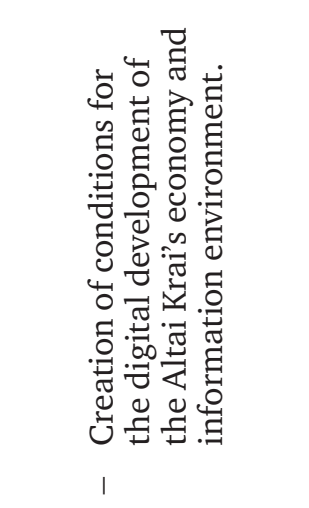 & \\
\hline 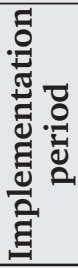 & 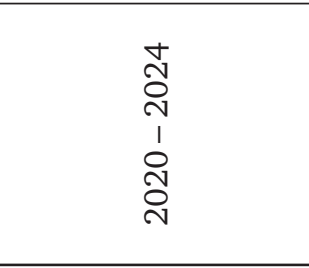 & \\
\hline $\begin{array}{c}\text { Z् } \\
\text { Z }\end{array}$ & 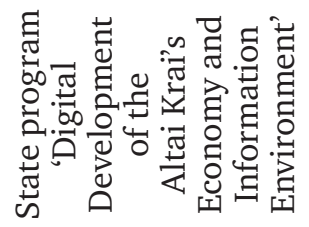 & \\
\hline 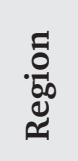 & 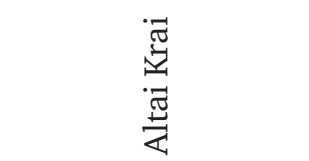 & \\
\hline
\end{tabular}




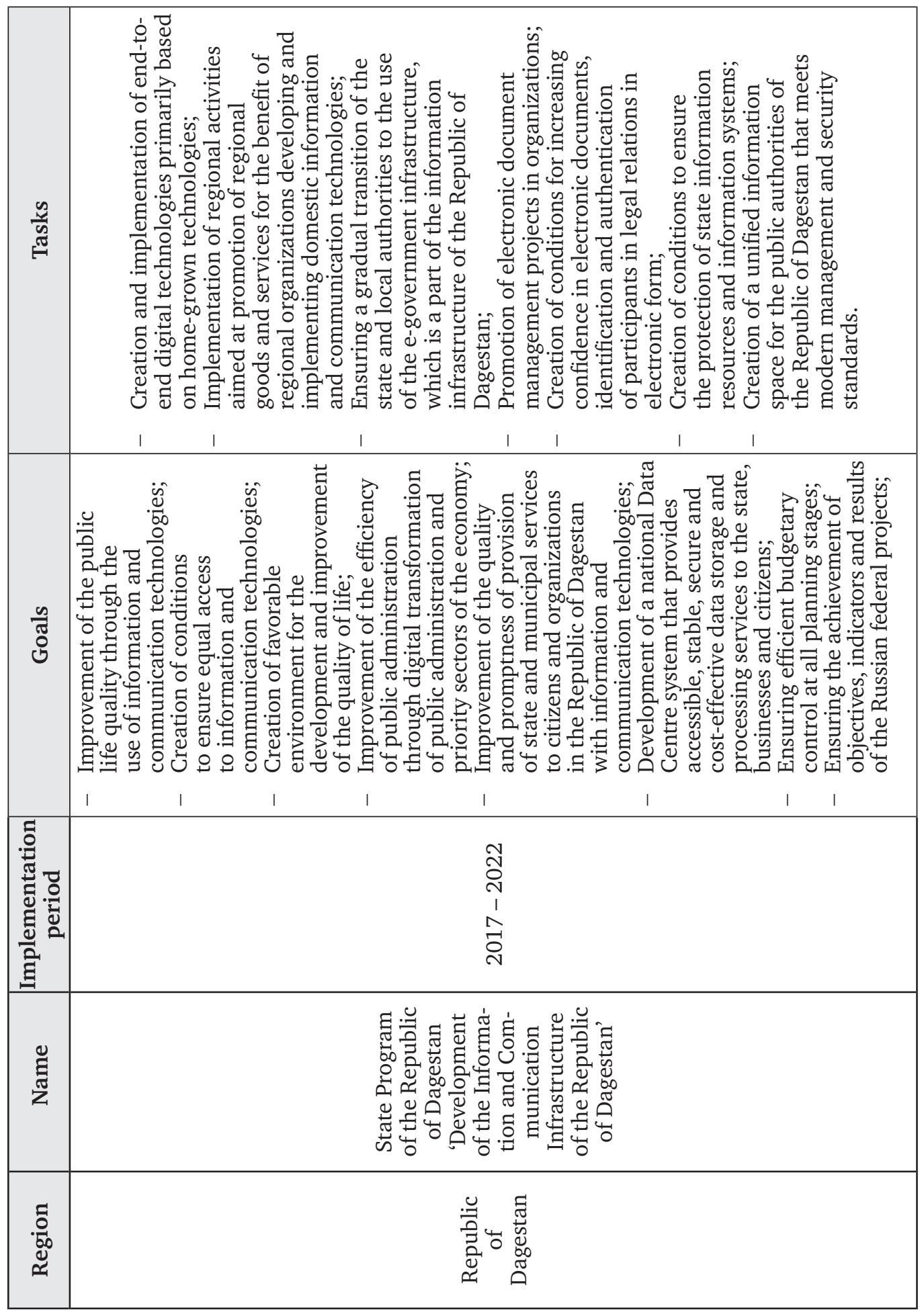




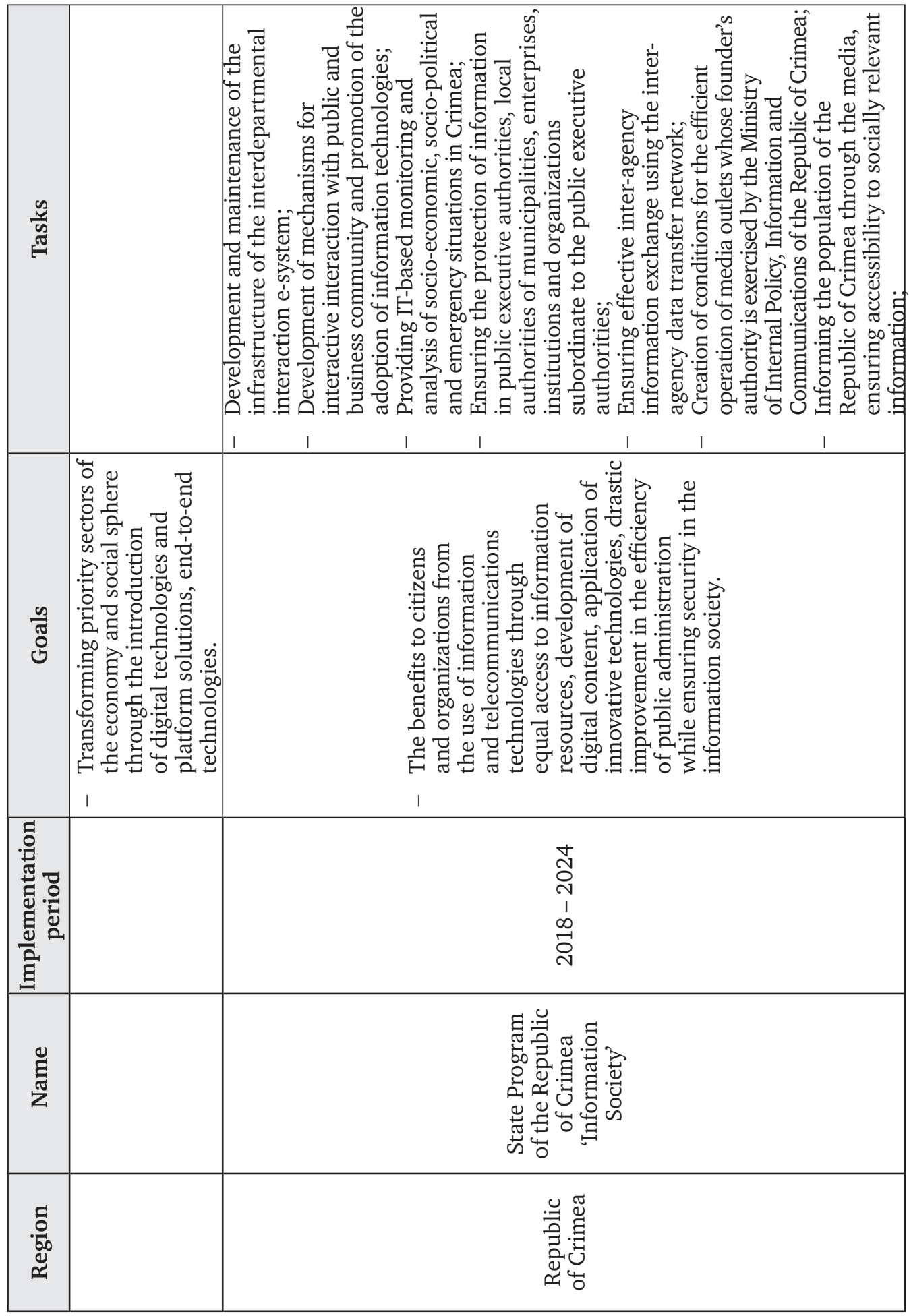




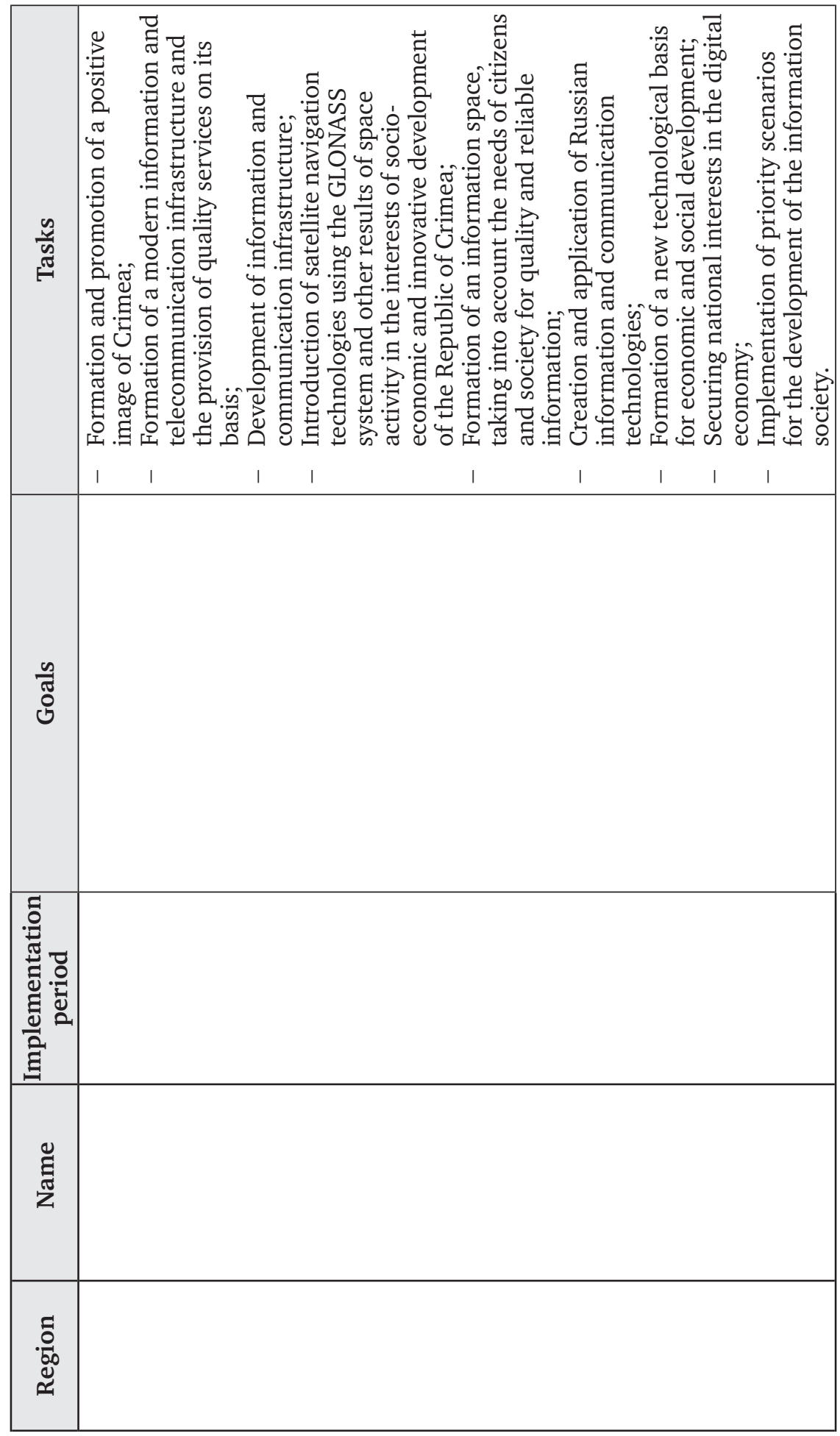




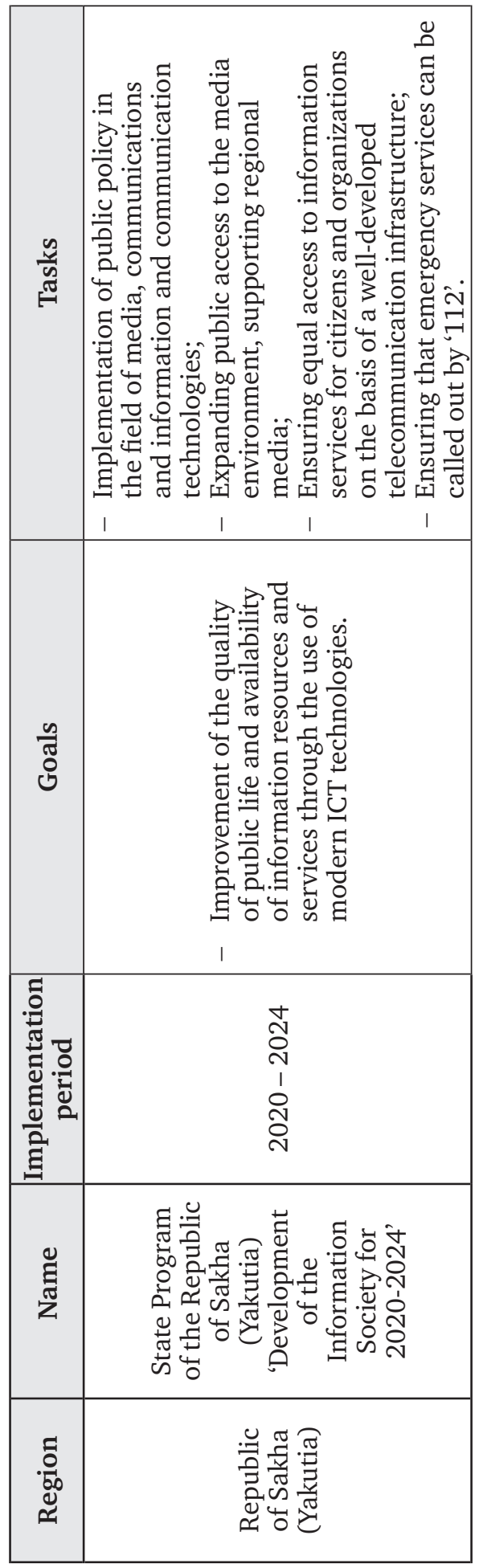




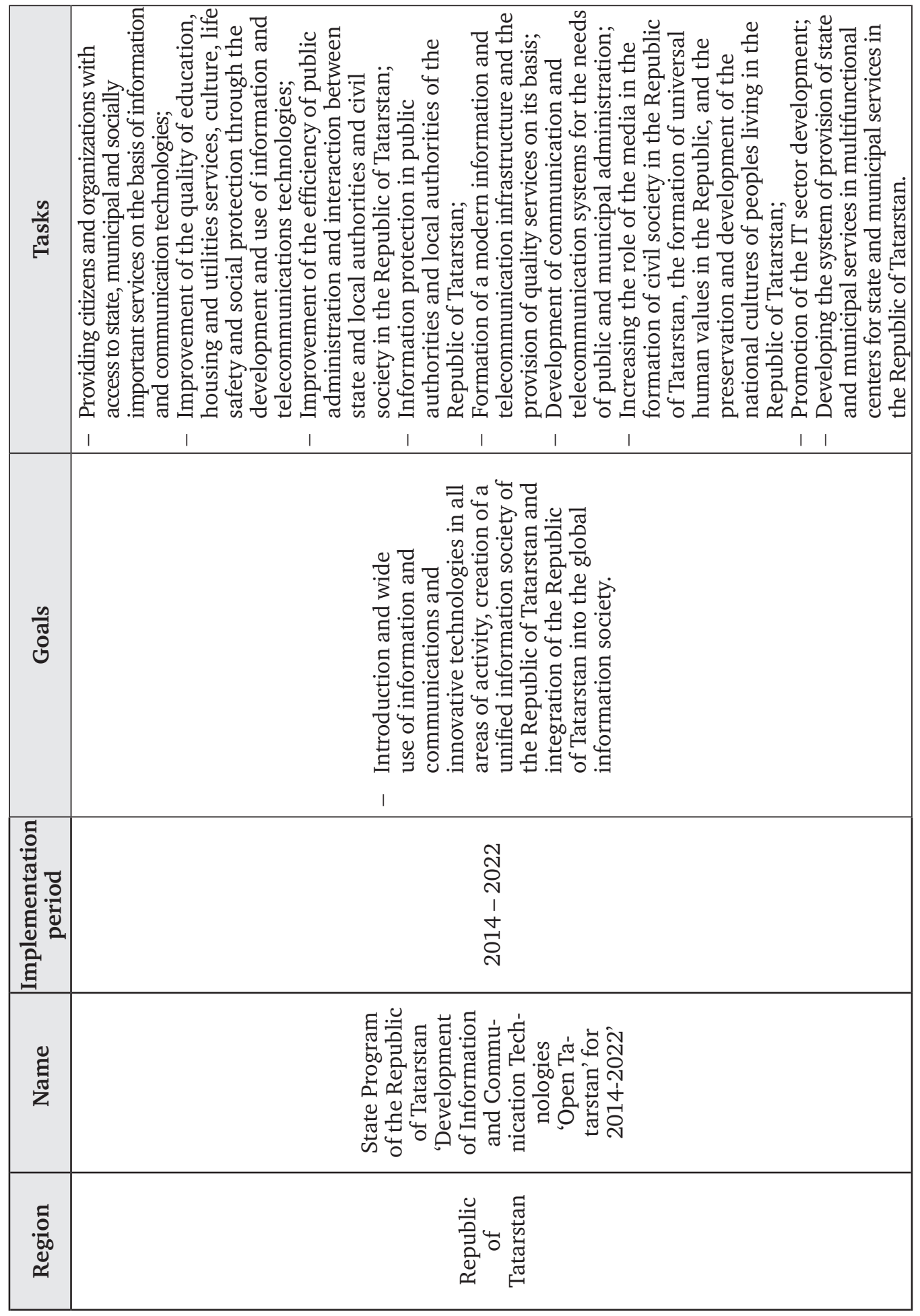


Based on the analysis of the tasks of these programs, priority categories have been identified related to addressing the challenges of the digital divide in the regions. (See Figure 1).

\section{Priority areas of elimination of the digital divide}

Figure 1 in the federal subjects of the Russian Federation (based on the analysis of state programmes of the subjects)

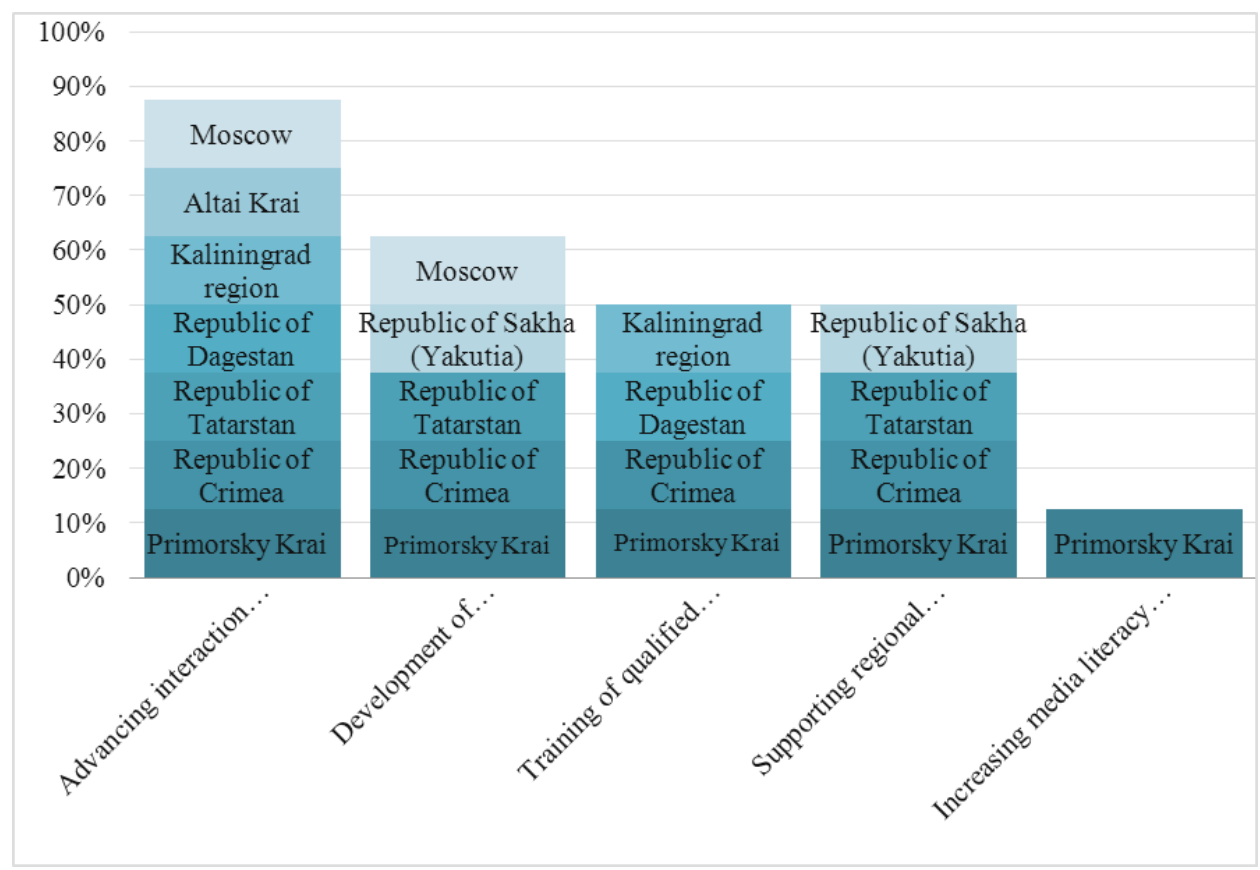

At present, almost in all federal subjects analysed, the priority is to advance and improve the quality of the 'population-executive authorities' interaction, as well as to ensure the access by citizens and organizations to public and municipal services through ICTs. The state program of the Kaliningrad region and the current program 'Development of Information and Communication Technologies in the Republic of Tatarstan' are aimed at improving the quality of state and municipal government. The authorities of the Republic of Crimea ${ }^{4}$,

${ }^{4}$ State program of the Republic of Crimea 'Information Society'. Available from: http://docs.cntd.ru/document/446680303 
Republic of Dagestan ${ }^{5}$, Kaliningrad region ${ }^{6}$ and the Primorsky Krai ${ }^{7}$ are focused on these tasks as well.

The indicators of the program of Altai $\mathrm{Krai}^{8}$ include such criteria as 'the level of provision of residents with local print media' and 'access of the population to the broadcast of the regional TV channel Katun 24', however, the key indicators are 'the share of interactions of citizens and commercial organizations with the executive authorities of the Altai Krai and local governments, public property organizations of the Altai Krai and municipal property, carried out digitally' as well as 'the number of views of the official website of the Government of the Altai Krai'".

The analysis of the documents shows that the state programmes of the certain regions are fully devoted to the problem of promoting and improving the quality of interaction between the population and the executive authorities, as well as ensuring access of citizens and organizations to state and municipal services through ICT. In particular, this is the case with the documents of Altai Krai: the objectives of its current programme are to 'increase the transparency of the activities of the executive authorities, local governments and improve the administrative and management processes in these bodies; improve the accessibility and quality of public and municipal services for the public and business through the use of modern ICT; improve the efficiency of the civil and municipal service, as well as the performance of public civil and municipal employees $^{10}$. Similar situation is observed in the Republics of Crimea and Tatarstan, where six out of nine tasks of the state programs are associated with improving the quality and accessibility of the state and municipal services, as well as the efficiency of the state and municipal government in the context

${ }^{5}$ State Program of the Republic of Dagestan 'Development of Information and Communication Infrastructure of the Republic of Dagestan'. Available from: http:// docs.cntd.ru/document/445095685

${ }^{6}$ State program of the Kaliningrad region 'Digital Transformation in the Kaliningrad Region'. Available from: http://docs.cntd.ru/document/561539248

${ }^{7}$ State program of the Primorsky region 'Information Society'. Available from: http://docs.cntd.ru/document/561434379

${ }^{8}$ State program 'Digital development of the economy and information environment of the Altai Krai'. Available from: http://docs.cntd.ru/document/561699005

${ }^{9}$ State program 'Improvement of state and municipal government in the Altai Krai'. Available from: https://www.altairegion22.ru/gov/administration/isp/ uprgosslu/gosprogramma-sovershenstvovanie-upravleniya/

${ }^{10}$ State program 'Improvement of state and municipal government in the Altai Krai'. Available from: https://www.altairegion22.ru/gov/administration/isp/ uprgosslu/gosprogramma-sovershenstvovanie-upravleniya/ 
of digitalization. The development of information and communication infrastructure, as well as ensuring equal access of citizens and organizations to information services on its basis is a priority for most regions included into our sample - Republic of Sakha (Yakutia), Republic of Crimea, Republic of Tatarstan, as well as the Primorsky Krai and Moscow.

Not to such extent, but still sufficient attention in governmental programs focused on overcoming the problems of digital divide, is given to the support and adaptation to the digital environment of the regional media in order to increase their role in informing the population and, most importantly, in the formation of civil society. Four out of eight analyzed programs include items related to the training of qualified personnel, geared towards ensuring efficient management in the implementation of ICTs and communications. In particular, in the state program of the Primorsky Krai 'Information Society' the focus falls on improving the system of training IT-specialists; in the Kaliningrad region - personnel training for work in the area of information and communication technologies; and in the documents 'Development of information and communication infrastructure of the Republic of Dagestan' and 'State program of the Republic of Crimea 'Information Society'- development and implementation of domestic information and communication technologies.

However, the analysis revealed that little attention is currently given to the problem of increasing the population's media literacy at the regional level (See Figure 1). The only program to include this item is the state program of the Primorsky Krai 'Information Society' for 2020-2027, which combines it with the task focused on the training of IT-specialists. Its wording is as follows: 'development of digital skills and improvement if the training of information technology and communications professionals by assisting educational institutions in the development of new educational programs'.

To sum up, it can be concluded that in most of the regions studied, the authorities are primarily focused on overcoming the first level of the digital divide, that is they seek to expand the citizens' access to modern information and communication infrastructure, state and municipal digital services. However, the skills and ability to use them have not yet become priorities in the state documents of the federal subjects of the Russian Federation.

\section{Digital media literacy:} Theoretical approaches in the Russian context

The concept of media literacy, which originally emerged as a result of the spread and growing popularity of cinematography and television, together with the 
awareness of the need to introduce new educational programs to understand them, has been given new meanings over the recent decades (Fedorov, 2004; Lapin, 2020). The term 'media literacy' has been used in the international research since 1970s, but for a long time it coexisted with concepts such as functional, audiovisual and information literacy (Houk, Bogart, 1974; Sharikov, 2013). The term 'information literacy' made its way into academic discourse in 1970s, when foreign scholars first underlined the importance of individuals learning a new set of skills, including the ability to identify and use information (Burchinal, 1976; Hamelink, 1976; Owens, 1976).

In 1989, the Association of American Libraries defined the basic competencies of an information literate person: the ability to locate, evaluate, recognize and effectively use the information needed to perform any task or make any decision ${ }^{11}$. These skills have subsequently also been enshrined in a number of important international documents: The Prague Declaration 'Towards an Information Literate Society' (2003) ${ }^{12}$, The Alexandria Proclamation on Information Literacy and Lifelong Learning $(2005)^{13}$, Fez Declaration on Media and Information Literacy (2011) ${ }^{14}$.

The process of IT and media digitalization together with the emergence of the new types of media introduced the need for individuals to acquire new competencies that can not only give them access to information materials, but also help them create the types and formats of digital media content they need for personal and professional purposes, as well as avoid possible risks in the digital information space. In 1997, Paul Gilster coined the term 'digital literacy', referring to the skill to critically comprehend and analyze information produced by computer technology. Subsequently, the concept has been articulated in the academic community as the meaningful use of digital technology by humans as a tool for access, integration and synthesis of information resources, knowledge acquisition and communication (Kress, 2003; Martin, 2006; Waks, 2006).

${ }^{11}$ Evaluating Information: Information Literacy. Available from: https://libguides.ala.org/InformationEvaluation/Infolit

12 The Prague Declaration 'Towards an Information Literate Society' (2003). Available from: http://www.unesco.org/new/fileadmin/MULTIMEDIA/HQ/CI/ $\mathrm{CI} /$ pdf/PragueDeclaration.pdf

13 The Alexandria Proclamation on Information Literacy and Lifelong Learning (2005). Available from: https://www.ifla.org/publications/beacons-of-the-information-society-the-alexandria-proclamation-on-information-literacy

${ }^{14}$ Fez Declaration on Media and Information Literacy. Available from: http:// www.unesco.org/new/fileadmin/MULTIMEDIA/HQ/CI/CI/pdf/news/Fez\%20 Declaration.pdf 
Though, at the professional level, the concepts of media literacy and information literacy have been treated independently for many years, computer literacy and technology skills served as key linking elements. In 2007, UNESCO (United Nations Educational, Scientific and Cultural Organization) and IFLA (The International Federation of Library Associations and Institutions) proposed to merge the concepts and to use them exclusively as 'media and information literacy' in the future. This combined notion should encompass all competencies, including digital and technological literacy. According to the IFLA Media and Information Literacy Guidelines, it is not only a fundamental human right in an ever-evolving digital, interdependent global world, but also an essential tool for bridging the information (digital) divide ${ }^{15}$.

This study focuses specifically on digital skills and competencies, which could be formed not only through the practical activities of each user, but also through the implementation of media education programs developed within the framework of media education models in Russia. In this context, media education is considered as an intrinsic instrument to overcome the digital divide at various levels by adapting the historical experience of cinema education, information literacy and embracing each of the three levels of digital inequality (Gladkova, Garifullin, Ragnedda, 2019). These include the level of access to the Internet and ICT, the level of digital competencies of users and digital literacy and the level of social benefits users gain from competent and critical use of digital technologies in social and private life.

At the first level, most users need to access the Internet and understand the basic concepts associated with the Internet use, such as traffic, speed, provider, etc.; as well as technical issues related to the use of ICT. Accordingly, it is important to introduce the existing practical-utilitarian models of media education, developed in 1935-1955 to train people in the use of technologies. At the second level, users need skills to quickly search for the necessary information on the Internet and use online resources for personal and professional purposes, which in the framework of media education could be considered as core media competencies. The third level deals with social benefits, users might gain through the implementation of sociocultural models of media education. Sociocultural model has been developing since 1986 and is in its essence the latest existing model of the Russian media education. In addition to the above said it should be noted that media education allows the user not only to effectively use the Internet and ICTs, but also to develop as a full-fledged participant in the digital environment.

${ }^{15}$ IFLA recommendations on media and information literacy. Available from: https://ifap.ru/ofdocs/ifla/ifla16.pdf 
However, the implementation of media education in Russia has been closely related to official government policies at the federal and regional levels. In order to identify the aims and main focus of the policies to develop media literacy, a study of the legislative documents of eight federal subjects of the Russian Federation (Moscow, Republic of Crimea, Primorsky Krai, Altai Krai, Kaliningrad Region, Republic of Tatarstan, Republic of Sakha (Yakutia), Republic of Dagestan) was conducted in late 2020/early 2021. A number of state official and industrial, professional documents and programs has been selected. The first group of documents includes the State Information Society Program ${ }^{16}$ and 'Strategy, goals, objectives and methods of information education for children and young people' by the Federal Service for Supervision of Communications, Information Technology and Mass Media $^{17}$. The second group includes the Moscow Declaration on Media and Information Literacy ${ }^{18}$, the RAEC Manifesto 'The Russian Internet in the 21st Century: Child Safety'19 and several other documents. This collective approach by governmental and professional organizations to developing public media literacy is a result of the co-regulatory efforts, actively used by states to combat misinformation.

The need to develop media literacy is now recognized internationally, as confirmed by official documents (UNESCO, IFLA, etc.). However, the solution to this problem in practice directly depends on the national regulation and information policy. Improving media literacy is a priority in the State Information Society Program, but limited access to ICTs and an insufficient level of citizens' skills require systematic work at all levels to achieve this objective.

During the meeting on technology development in the field of artificial intelligence on May 30, 2019, Russian President Vladimir Putin stressed the need to provide digital education and introduce retraining programs in digital technologies. In December 2019, as part of the federal project 'Workforce for the

${ }^{16}$ State Information Society Program. Available from: https://digital.gov.ru/ru/ documents/4137/

17 'Strategy, goals, objectives and methods of information education for children and young people'. Available from: https://rkn.gov.ru/docs/Razdel_20_koncepcija_2901.pdf

${ }^{18}$ The Moscow Declaration on Media and Information Literacy. Available from: http://ifapcom.ru/files/News/Images/2012/mil/Moscow_Declaration_on_MIL_ rus.pdf

${ }^{19}$ The RAEC Manifesto 'The Russian Internet in the 21st Century: Child Safety'. Available from: http://old.raec.ru/upload/files/ 
Digital Economy', an official digital literacy educational resource was launched to educate citizens on the use of digital technologies, in particular, helping them master key principles of information security ${ }^{20}$. According to project objectives, 10 million people are expected to benefit from digital literacy programs by 2024.

In spring 2020, as part of the national program 'Digital Economy in the Russian Federation', an educational event called 'Digital Dictation' was held in all regions of the Russian Federation. The aim of the campaign was to test Russian citizens in two age categories (14-18 years old; 18 and over) online to identify the level of their digital skills and competences. The average level of digital literacy among participants $\left(330,148\right.$ people) was 72.5 per cent ${ }^{21}$. In October 2020, a digital literacy education project was launched on the basis of the 'Digital Dictation' to remedy the lack of computer competencies among the population of the Russian Federation. At the professional level, Russia has also adopted draft media literacy programs, which are largely based on the UNESCOapproved Media Education concept ${ }^{22}$. The programs were implemented as part of the UNAOC (The United Nations Alliance of Civilizations) international media education portal and focused mainly on media and information literacy for children and youth but were not embedded in the broader context of addressing the digital divide.

As part of the study, the texts of official documents (State Information Society Program and Strategy, goals, objectives and methods of information education for children and young people), professional documents (Moscow Declaration on Media and Information Literacy, RAEC Manifesto 'The Russian Internet in the 21st Century: Child Safety', etc.) and texts of federal programs (Workforce for the Digital Economy, Digital Dictation, etc.) have been studied. Based on the content analysis of the texts, we believe the following factors can be considered obstacles to the development of relevant competencies among Russians: underdeveloped digital infrastructure, remaining digital divide, insufficient attention to the linguistic and cultural diversity of Russia, which in fact is unique and can hardly be found elsewhere in the world, legal restrictions on access, ownership and dissemination of information,

${ }^{20}$ Educational resource 'Digital literacy'. Available from: цифроваяграмотность.рф

${ }^{21}$ All-Russian educational campaign to determine the level of digital literacy. Available from: https://digitaldictation.ru

${ }^{22}$ Media Education - UNESCO. Available from: http://portal.unesco.org/ci/en/ ev.php-URL_ID $=1653 \& U R L \_D O=$ DO_TOPIC\&URL_SECTION $=201 . \mathrm{html}$ 
the problem of long-term storage of personal information in digital formats, lack of interagency cooperation and interdisciplinary interaction between stakeholders.

In order to examine the media literacy orientation of the regions studied, we carried out a monitoring of the media and official websites of the state institutions (Ministry of Digital Development, Communications and Mass Media of the Russian Federation, The Federal Service for Supervision of Communications, Information Technology and Mass Media, The State Duma of the Russian Federation, etc.). The study revealed a significant quantitative gap in the mentions of the key words 'media literacy' and 'digital literacy'. (See Figure 2).

Figure 2

Media and digital literacy mentions in the media and on official websites of government officials

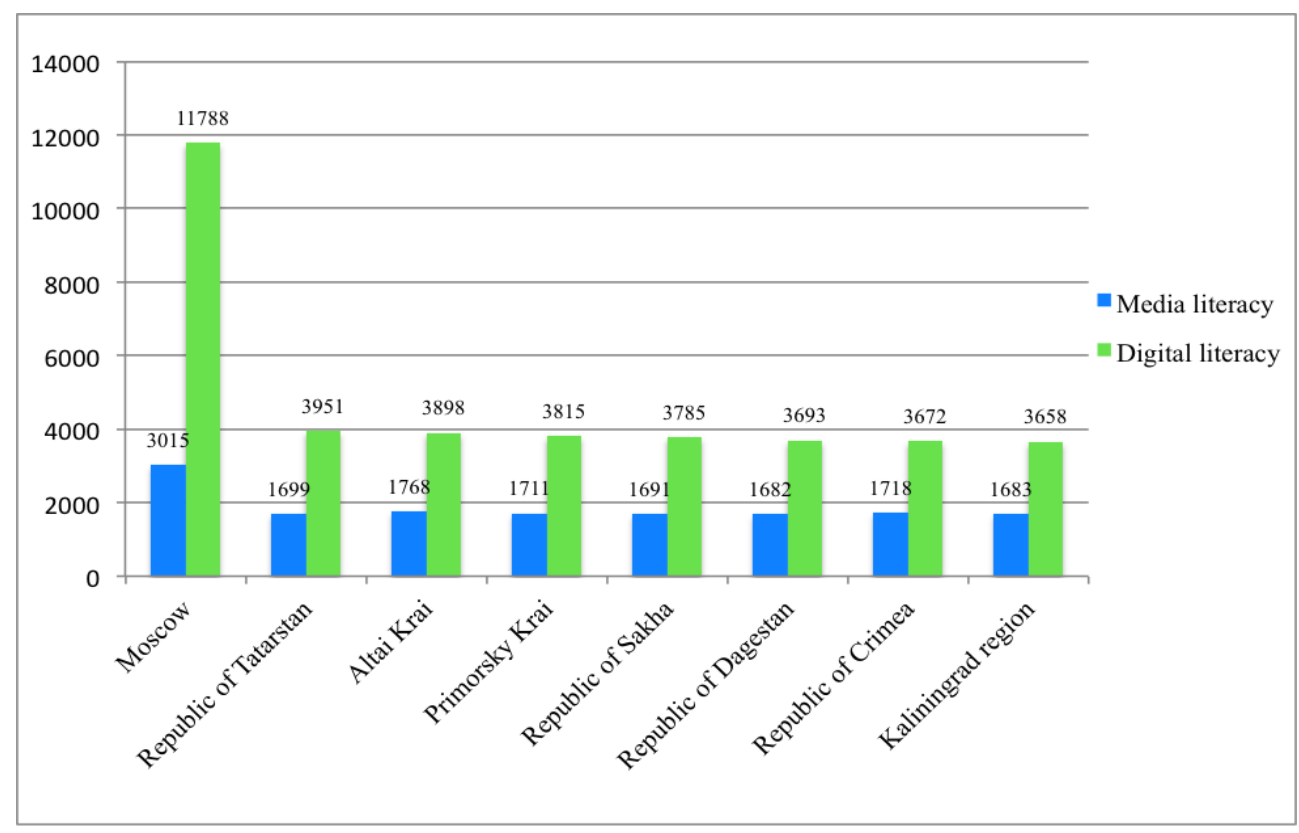

In short, the frequency analysis identified the problem of inconsistency of terminology in the texts. At the state level, the term 'digital literacy' is predominantly used and the objectives of federal programs are aimed at developing digital competencies of citizens, while in the professional Russian 
community the term 'digital literacy' is seen as part of a broader concept - 'media and information literacy'. Thus, the analysis of the texts of federal programs of developing media literacy, as well as a monitoring of the media and information from official institutions to identify the use of terminology, revealed a significant discrepancy, both in the definition of terms 'media literacy', 'information literacy' and 'digital literacy' and in the methods and approaches of outreach. We believe that media literacy, being a crucial tool for overcoming the digital divide in Russia, is becoming difficult to tackle due to the lack of uniform, federally approved standards and project requirements. This underlines the importance of the state policy aimed at overcoming digital divide and increasing the level of media and digital literacy, which we will examine closely in the next part of the paper.

\section{'Digital passport' of the Russian regions}

Having analyzed the current state of the regulatory mechanisms and media/ digital literacy development trends in several federal subjects of the Russian Federation, we revealed a need for a clear and consistent tool to describe, monitor and fully understand ongoing digitalization progress in the country. We believe a 'digital passport', combining a number of characteristics important for each region, could be a good instrument here, allowing for inner- and crossregional analysis and comparisons - in the digital divide context and in the broader context as well. 'Digital passport', as we envision it, should include the following data:

- national demographic data (population size; male and female population; presence/absence of titular nations; most common languages in public use)

- legal information (federal documents regulating the process of digitalization and implementation of digital technologies; local documents regulating the process of digitalization and implementation of digital technologies; reports on the implementation of digitalization programs; priority areas of digitalization; presence/absence of state or local programs of digital divide elimination)

- digital saturation of the region (Internet penetration rate; average cost of provider services; available Internet access speed; average daily Internet audience; data on digital resources use in the region; regional features of digitalization. i.e. main priority areas)

- digital literacy of the region (level of computerization; data on the appeal to the online public services of state organizations excluding 
small businesses; level of computer literacy; presence/absence of online platforms dedicated to the activities of the government, the head of the region and local authorities; online platforms allowing the population to participate in regional development issues solution)

As part of this study, we tested the model of 'digital passport' in eight federal subjects of Russia: Moscow, Republic of Tatarstan, Republic of Sakha (Yakutia), Republic of Crimea, Primorsky Krai, Altai Krai, Kaliningrad region and Republic of Dagestan. Most data such as population size, presence/absence of titular nations, most common languages in public use, federaland local documents regulating the process of digitalization and implementation of digital technologies, Internet penetration rate, average cost of the provider services, available Internet access speed, regional features of digitalization and all criteria of digital literacy were available in open sources.

Still, some criteria were impossible to examine because of absence of the open statistics, although we suppose regional governments might have access to them. The most complete data were found for the Russian capital, probably due to it being the most digitally developed city in Russia. While the Republic of Dagestan turned out to be the region with the least amount of data available in open sources. It is important to mention that some of the regions, such as Primorsky Krai and Republic of Dagestan, do not have any local documents regulating the process of digitalization and implementation of digital technologies in open sources, which allows to conclude that their local digitalization processes are regulated only by federal documents and laws. Furthermore, only Moscow region provides open access information about the federal state or local programs of overcoming digital divide. To assess the digital saturation of the region we used the data provided by Yandex, Mediascope, TNS, NAFI and Federal State Statistics Service, although some of them (Yandex and NAFI) contains outdated data. Moreover, only one criterion, that is statistics on digital resources use in the region, was not available in open sources.

Data provided by the Federal State Statistics Service, Digital Dictation reports and open government resources were used as data source on digital literacy. It was discovered that the Republic of Tatarstan ranks first in the level of regional computerization criterium (99.7 per cent), Moscow is on the second place (99.4 per cent) and Altai Krai is on the third place (96.2 per cent). The least computerized region is the Republic of Dagestan (62.7 per 
cent). According to the statistics on the appeal to the online public services of the state organizations Moscow keeps the first place (84.4 per cent), followed by the Republic of Tatarstan (80.7 per cent) and Altai Krai (79.5 per cent). The Republic of Dagestan is once again in last place (43.1 per cent). All the mentioned regions maintain online platforms covering the activities of the government, the head of the region and local authorities and online platforms, allowing the population to participate in debates and decision making of regional development issues solution. In the digital literacy level first place belongs to Kaliningrad region ( 7.53 out of 10 points), Moscow is the second leading state (7.33 out of 10 points), followed closely by the Republic of Tatarstan (7.31 out of 10 points). The last place is taken by the Republic of Dagestan (6.56 out of 10 points).

As an example of digital passport use we provide data of two mentioned regions: Moscow as the region with the most developed digital infrastructure and Republic of Dagestan as the least digitally developed region in the sample. The table below (see Table 2) shows the differences in all the indicators mentioned above and allows to see the contrast between the states of digital development of the Russian capital and the regions.

Table 2

'Digital passports' of Moscow and the Republic of Dagestan

\begin{tabular}{|l|l|l|l|}
\hline \multicolumn{1}{|l|}{ Indicators } & Region & Moscow & \\
\cline { 2 - 4 } & $\begin{array}{l}\text { Population size } \\
\text { (Rosstat data) }\end{array}$ & 12678079 & $\begin{array}{l}\text { Republic } \\
\text { of Dagestan }\end{array}$ \\
\cline { 2 - 4 } $\begin{array}{l}\text { National } \\
\text { Demographic } \\
\text { data }\end{array}$ & $\begin{array}{l}\text { Male and female } \\
\text { population }\end{array}$ & No data available & No data available \\
\cline { 2 - 4 } & $\begin{array}{l}\text { Presence/absence } \\
\text { of titular nations }\end{array}$ & None & $\begin{array}{l}\text { 14 nationalities } \\
\text { (no titular nations) }\end{array}$ \\
\cline { 2 - 4 } & $\begin{array}{l}\text { Most common } \\
\text { languages in } \\
\text { public use }\end{array}$ & Russian & $\begin{array}{l}\text { Russian, Avar, Agul, } \\
\text { Azeri, Dargin, Kumyk, } \\
\text { Lak, Lezghin, Nogai, } \\
\text { Rutul, Tabasaran, Tat, } \\
\text { Tsakhur, Chechen }\end{array}$ \\
\hline
\end{tabular}




\begin{tabular}{|c|c|c|}
\hline $\begin{array}{l}\text { Legal } \\
\text { information }\end{array}$ & $\begin{array}{l}\text { Federal } \\
\text { documents } \\
\text { regulating } \\
\text { the process } \\
\text { of digitalization } \\
\text { and } \\
\text { implementation } \\
\text { of digital } \\
\text { technologies }\end{array}$ & $\begin{array}{l}\text { 1. Federal Law 'On Information, Information } \\
\text { Technologies and Information Protection' of } \\
\text { July } 27,2006 \text { N 149-FZ (last edition) }{ }^{23} \text {. } \\
\text { 2. Decree of the Government of the Russian } \\
\text { Federation 'On approval of the state program' } \\
\text { Information Society (2011-2020)'24. } \\
\text { + Order on amendments }{ }^{25} \text {. } \\
\text { 3. Decree of the President of the Russian } \\
\text { Federation of May } 9 \text {, } 2017 \text { N } 203 \text { 'On } \\
\text { the Strategy for the Development of the } \\
\text { Information Society in the Russian Federation } \\
\text { for } 2017-2030 \text { '26. } \\
\text { 4. Strategy for the development of the } \\
\text { information technology industry in the } \\
\text { Russian Federation for } 2014 \text { - } 2020 \text { and for } \\
\text { the future until } 2025 \text { (clause } 12 \text {. Improving } \\
\text { the literacy of the population in the field of } \\
\text { information technology) } \\
\text { 5. Order of the Ministry of Telecom and } \\
\text { Mass Communications of the Russian } \\
\text { Federation 'On holding an open tender for } \\
\text { the right to conclude a state contract for the } \\
\text { implementation of research work on the topic: } \\
\text { 'Assessment of the current state and prospects } \\
\text { of changing the level of media literacy of } \\
\text { the population of the Russian Federation on } \\
\text { the basis of national monitoring of media } \\
\text { behavior. Development of criteria for an in- } \\
\text { depth assessment of the population's media } \\
\text { literacy, including the quality of information } \\
\text { consumption'28. }\end{array}$ \\
\hline
\end{tabular}

23 Federal Law 'On Information, Information Technologies and Information Protection' of July 27, 2006 N 149-FZ (last edition). Available from: http://www. consultant.ru/document/cons_doc_LAW_61798/

${ }^{24}$ Decree of the Government of the Russian Federation 'On approval of the state program' Information Society (2011-2020)'. Available from: https://digital.gov.ru/ ru/documents/4137/

25 Order on amendments. Available from: https://digital.gov.ru/ru/ documents/3596/ http://docs.cntd.ru/document/557063853

${ }^{26}$ Decree of the President of the Russian Federation of May 9, 2017 N 203 'On the Strategy for the Development of the Information Society in the Russian Federation for 2017-2030'. Available from: http://base.garant.ru/71670570/\#ixzz6cuhlugZ9

27 Strategy for the development of the information technology industry in the Russian Federation for 2014 - 2020 and for the future until 2025 (clause 12. Improving the literacy of the population in the field of information technology). Available from: https://digital.gov.ru/ru/documents/4084/

${ }^{28}$ Order of the Ministry of Telecom and Mass Communications of the Russian Federation. Available from: 'https://digital.gov.ru/ru/documents/4314/ 


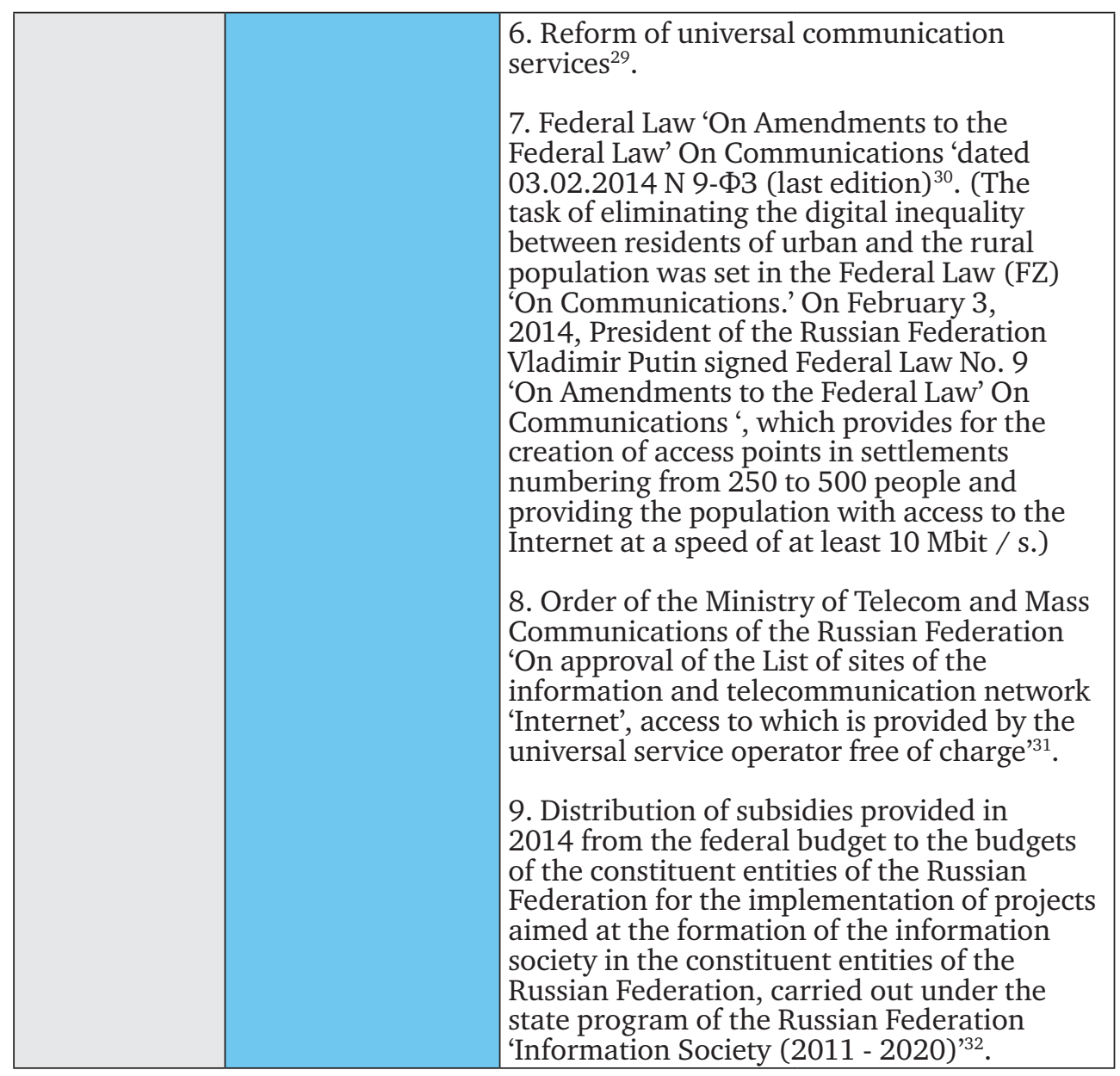

${ }^{29}$ Reform of universal communication services Available from: https://digital. gov.ru/ru/activity/directions/193/

30 Federal Law 'On Amendments to the Federal Law' On Communications 'dated 03.02.2014 N 9-Ф3 (last edition). Available from: http://www.consultant.ru/ document/cons_doc_LAW_158410/

31 Order of the Ministry of Telecom and Mass Communications of the Russian Federation 'On approval of the List of sites of the information and telecommunication network 'Internet'.

Available from: https://digital.gov.ru/ru/documents/4761/

32 Distribution of subsidies provided in 2014 from the federal budget to the budgets of the constituent entities of the Russian Federation for the implementation of projects. Available from: https://digital.gov.ru/ru/documents/4392/ 


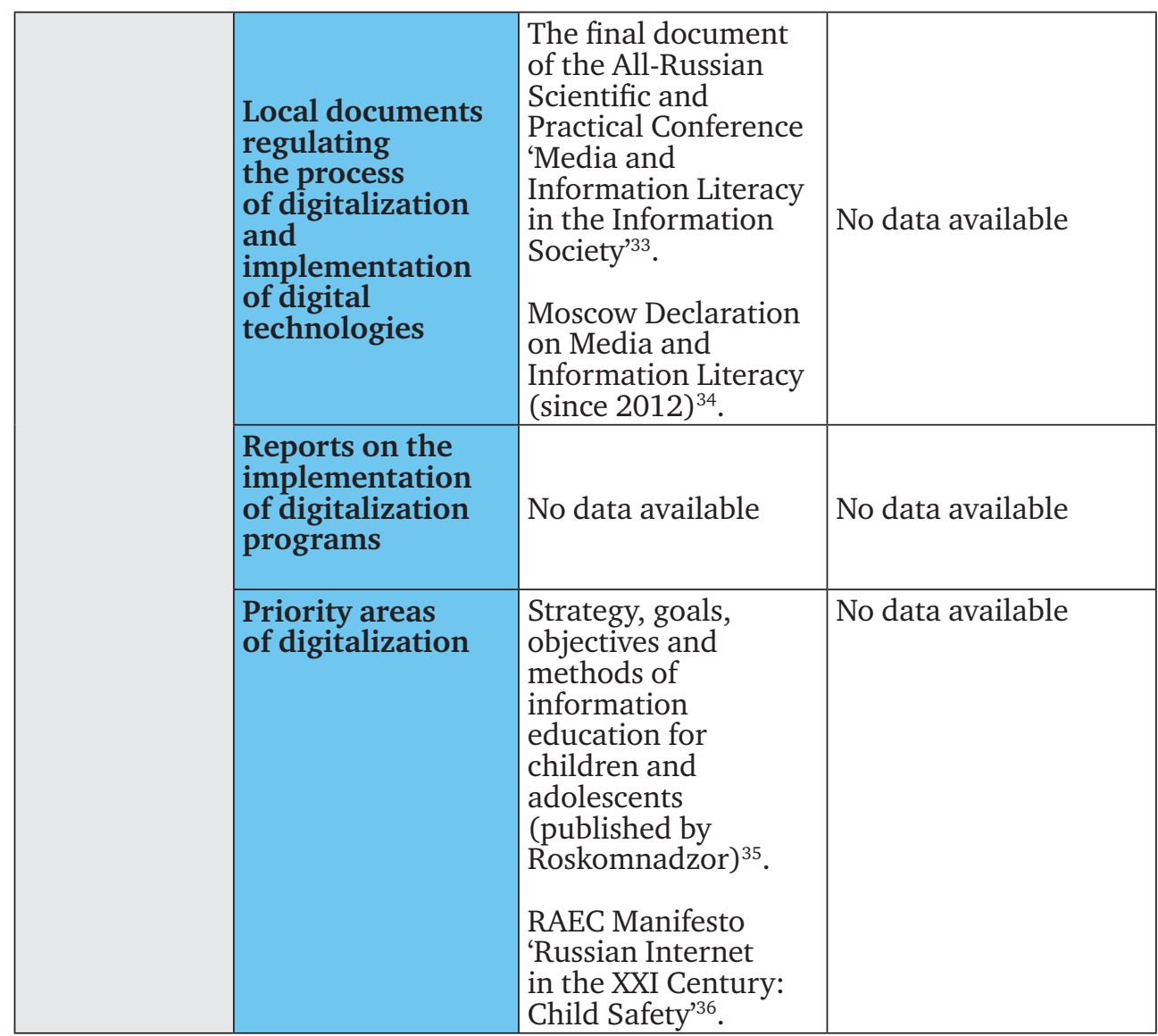

33 The final document of the All-Russian Scientific and Practical Conference 'Media and Information Literacy in the Information Society'. Available from: http:// www.ifapcom.ru/files/News/Images/2013/mil/mil_decl_rus_2013.pdf

${ }^{34}$ Moscow Declaration on Media and Information Literacy (since 2012). Available from: http://ifapcom.ru/files/News/Images/2012/mil/Moscow_Declaration_on_ MIL_rus.pdf

https://iite.unesco.org/ru/mig/

35 Strategy, goals, objectives and methods of information education for children and adolescents (published by Roskomnadzor). Available from: https://rkn.gov.ru/ docs/Razdel_20_koncepcija_2901.pdf

36 RAEC Manifesto 'Russian Internet in the XXI Century: Child Safety'. Available from: http://old.raec.ru/upload/files/ 
Theorizing Russian model of the digital divide

\begin{tabular}{|c|c|c|c|}
\hline & $\begin{array}{l}\text { Presence/absence } \\
\text { of state or local } \\
\text { programs } \\
\text { of digital divide } \\
\text { elimination }\end{array}$ & $\begin{array}{l}\text { Project 'Media' } \\
\text { of Rosmolodezh } \\
\text { (direction 'Involvement } \\
\text { of youth in the work } \\
\text { of the media (youth } \\
\text { media)') }{ }^{37} \text {. } \\
\text { 'Media Literacy for } \\
\text { Teachers' program } \\
\text { of the Faculty } \\
\text { of Pedagogical } \\
\text { Education, Moscow } \\
\text { State University } \\
(2020)^{38} \text {. }\end{array}$ & $\begin{array}{l}\text { Federal project aimed } \\
\text { at increasing the level } \\
\text { of digital literacy (DG) } \\
\text { of residents of Russia } \\
\text { (launch in Dagestan, } \\
2016)^{39} \text {. }\end{array}$ \\
\hline \multirow{6}{*}{$\begin{array}{l}\text { Digital } \\
\text { saturation } \\
\text { of the region }\end{array}$} & $\begin{array}{l}\text { Internet } \\
\text { penetration rate }\end{array}$ & 79 per cent & 67 per cent \\
\hline & $\begin{array}{l}\text { Average cost of } \\
\text { provider services }\end{array}$ & 400 rubles per month & 613 rubles per month \\
\hline & $\begin{array}{l}\text { Available Internet } \\
\text { access speed }\end{array}$ & $35 \mathrm{Mb}$ per second & $22 \mathrm{Mb}$ per second \\
\hline & $\begin{array}{l}\text { Average daily } \\
\text { Internet audience }\end{array}$ & $\begin{array}{l}\text { All-Russian data from } \\
\text { MediaScope: } 73 \% \text { of } \\
\text { the population is the } \\
\text { audience of the Runet }\end{array}$ & No data available \\
\hline & $\begin{array}{l}\text { Data on digital } \\
\text { resources use } \\
\text { in the region }\end{array}$ & None & No data available \\
\hline & $\begin{array}{l}\text { Regional features } \\
\text { of digitalization. } \\
\text { i.e. main priority } \\
\text { areas }\end{array}$ & $\begin{array}{l}\text { Urban environment, } \\
\text { digital mobility, } \\
\text { urban economy, } \\
\text { safety and ecology, } \\
\text { digital government, } \\
\text { human and social } \\
\text { capital }\end{array}$ & $\begin{array}{l}\text { Communications, } \\
\text { healthcare, urban } \\
\text { environment, } \\
\text { construction, human } \\
\text { resources and } \\
\text { education }\end{array}$ \\
\hline & $\begin{array}{l}\text { Level of } \\
\text { computerization }\end{array}$ & 99,4 per cent & 62,7 per cent \\
\hline $\begin{array}{l}\text { Digital } \\
\text { literacy } \\
\text { of the region }\end{array}$ & $\begin{array}{l}\text { Data on the } \\
\text { appeal to the } \\
\text { online public } \\
\text { services of state } \\
\text { organizations } \\
\text { excluding small } \\
\text { businesses }\end{array}$ & 84,4 per cent & 43,1 per cent \\
\hline
\end{tabular}

${ }^{37}$ Project 'Media' of Rosmolodezh (direction 'Involvement of youth in the work of the media (youth media)'). Available from: https://fadm.gov.ru/activity/scope/5/details

${ }^{38}$ Media Literacy for Teachers' program of the Faculty of Pedagogical Education, Moscow State University (2020). Available from: http://fpo.msu.ru/index.php/ 2-uncategorised/314-mediagramotnost-dlya-prepodavatelej

${ }^{39}$ Federal project aimed at increasing the level of digital literacy (DG) of residents of Russia (launch in Dagestan, 2016). Available from: https://www.rspectr.com/ novosti/47650/povyshenie-urovnya-cifrovoi-gramotnostii 


\begin{tabular}{|l|l|l|}
\hline $\begin{array}{l}\text { Level of computer } \\
\text { literacy }\end{array}$ & 7,33 out of 10 points & 6,56 out of 10 points \\
$\begin{array}{l}\text { Presence/ } \\
\text { absence of } \\
\text { online platforms } \\
\text { dedicated to the } \\
\text { activities of the } \\
\text { government, } \\
\text { the head of the } \\
\text { region and local } \\
\text { authorities }\end{array}$ & ru/ & http://www.e-dag.ru/ \\
$\begin{array}{l}\text { Activity of heads } \\
\text { of subjects and } \\
\text { their dialogue } \\
\text { with the } \\
\text { population in } \\
\text { social networks }\end{array}$ & High & Low \\
$\begin{array}{l}\text { Online platforms } \\
\text { allowing the } \\
\text { population } \\
\text { to participate } \\
\text { in regional } \\
\text { development } \\
\text { issues solution }\end{array}$ & $\begin{array}{l}\text { Aktivniy } \\
\text { grazhdanin }\end{array}$ & \\
\hline
\end{tabular}

Concluding, we argue that the use of a 'digital passport' as an instrument to monitor regional digital divide could help to identify current trends and reveal shortfalls in digitalization processes in the regions of Russia, in order to further contribute to the development of state policies and combating digital divide. It might also allow for better understanding of the unique digital divide model in the country. The main advantage of a 'digital passport' model is that it can be easily adapted for every region with certain amendments depending on specific digital development features in each region. The use of four-component and multi-criteria structure of the 'digital passport' allows to study digital divide issue in Russia as a complex phenomenon, and to provide clear guidance for addressing this issue, tailored to the developmental characteristics of each region.

\section{Conclusion and recommendations}

Given significant differences in geographic, economic, cultural and societal terms typical for Russia, the problem of the 'digital divide' is a natural phenomenon for the country. Earlier studies on digital inequalities in Russia showed a correlation between the first and the second levels of the digital divide

40 Aktivniy grazhdanin. Available from: https://ag.mos.ru/home

${ }^{41}$ Active citizen of the Republic of Dagestan. Available from: https://ag.e-dag.ru/ 
(Gladkova, \& Ragnedda, 2020). In this case, some regions (for instance Far Eastern federal district) lacking behind by access can be the country's leaders by digital literacy, and vice versa - regions with good access and infrastructure availability can lag far behind by digital literacy index, e.g. Volga federal district (ibid). Previous research on Russia also articulated the important role of policymaking mechanisms in building a sustainable and efficiently developing society (Vartanova, 2001), which is particularly important given the specific character of Russia. However, as is revealed in this study, despite state involvement on both federal and regional levels aimed at minimizing digital inequality in the country, federal subjects still differ from each other significantly, when it comes to the spread and availability of ICTs, access to the Internet, population-state authority interaction, the use of state services online, etc.

We argue therefore in this paper that Russia represents an interesting and in many ways unique model of the digital divide due to its sociocultural, economic, political specifics, policy mechanisms, traditionally important role of the state, even climatic and geographical conditions that can affect availability of infrastructure in remote areas (Vartanova, \& Gladkova, 2019). Having analyzed digital literacy and media literacy in a broad cross-regional comparative perspective; state regulation of digitalization processes in Russia on federal and regional levels; and specific mechanisms for the analysis and further overcoming digital divide in the country, we believe a number of recommendations can be suggested to federal and local authorities for further bridging digital gap in the country.

First, we found out that in almost all federal subjects analysed, the priority is to advance and improve the quality of the population-state authority interaction, as well as to ensure that citizens and organizations have access to public and municipal services through ICTs. Much has been done in this respect, and a lot of programs in the Russian regions are aimed at improving accessibility, immediacy and quality of state and municipal e-services to the population, supporting digital economy development on a regional level, stimulating online communication between citizens and local authorities, and much more. However, the analysis showed that little attention is currently given to the problem of increasing the population's media literacy at the regional level. In this regard, we should reiterate the need for straightforward actions aimed at developing media education programs for all social, cultural, professional and age groups of the Russian population.

Second, closer attention should be given to increasing digital skills and competencies of Russian Internet users. Our study revealed the problem of 
inconsistency of terminology, with the term 'digital literacy' being predominantly used at the state level to mark the importance of the digital competencies development, and the term 'media and information literacy' being widely used in the professional Russian community as a broad term, which among other things encompasses 'digital literacy' concept. Still, regardless of the inconsistency of terminology, all analyzed federal and regional level documents and programs stress the importance of the digital skills development to ensure Russian Internet users can fully benefit - both professionally and personally - from being online. We believe an important field to develop here is media education: educational programs for students of secondary and high schools, specialized programs for adults, retired people and maybe even preschoolers can play a significant role in overcoming digital divide of the second level in Russia.

Lastly, we believe the use of a 'digital passport' model that we proposed in this study can be useful for all regions of the Russian Federation and possibly for other countries. We believe that 'digital passport' while providing a detailed overview of all three levels of the digital divide (access; skills; benefits from using Internet and ICTs) can be used both by scholars and policy makers engaged in developing strategies for overcoming digital divide, fostering digital inclusion and increasing digital capital (Gladkova, Vartanova, \& Ragnedda, 2020) of Russian Internet users. Furthermore, as noted above, the main advantage of the 'digital passport' is its potential to be easily adapted for every national/regional context depending on specific digital development features in each region, which makes 'digital passport' a universal model for the analysis of digital inequalities in a broader sense.

Concluding, we assume that digital gap will remain an issue in Russia, at least in the short term, regardless of the discussed above policies intended to overcome the divide. The reason lies in considerable differences between Russian regions in terms of Internet penetration rate, daily audience numbers, the cost and speed of connection, etc. A set of 'objective factors' related to the specific character of Russia (distances, climatic and geographical conditions, urbanization level, socioeconomic conditions, cost of laying optic fibre cables in remote parts of the country, etc.) may influence all three levels of the digital divide in the country and result in some regions being more technologically advanced than the others (Vartanova, \& Gladkova, 2019). In this case, the use of a 'digital passport' model can solve several problems: understanding digital divide as a two-sided problem, technological and social one; increasing the efficiency of the state policies to overcome digital divide by enforcing populationstate authority interaction; revealing main problems and weaknesses typical for 
each particular region; and finally suggesting measures for overcoming digital inequality, one of which might be placing high priority on media education and digital literacy programs aimed at bridging the digital gap.

\section{References}

ANDERSEN, N. (2002). New media and new media literacy: The horizon has become the landscape - new media are here, pp.30-35. transcript.

BOBKOV, V., GULYUGINA, A., \& ODINTSOVA, E. (2009). Regionalnoe neravenstvo kachestva i urovnya zhiznii ugrozy sotsialnoi bezopasnosti Rossii [The regional inequality of the quality and standards of living and the threats to the social security of Russia]. Federalizm, 1(53), pp. 135- 148.

BURCHINAL, L.G. (1976). The communication revolution: America's third century challenge. The Future of Organizing Knowledge: Papers Presented at the Texas A \& M University Libraries Centennial Academic Assembly. College Station, TX: A\&M University Library.

BYKOV, I., \& HALL, T. (2011). Tsifrovoe neravenstvo i politicheckie predpochteniya Internet-polzovatelei v Rossii [Digital divide and political preferences of Russian internet users]. Polis. Politicheskie Issledovaniya, 5: 151-163.

CARMI, E., \& YATES, S. J. (2020). Digital inclusion and data literacy. Internet Policy Review, 9(2). DOI: 10.14763/2020.2.1474

CASTELLS M. (2016). Vlast' Kommunikacii [Communication Power]. Moscow: HSE Publ.

CHIPEVA, P., CRUZ-JESUS, F., OLIVEIRA, T., \& IRANI, Z. (2018). Digital divide at individual level: Evidence for Eastern and Western European countries. Government Information Quarterly, 35(3), pp. 460-479.

DEVIATKO, I. (2013). Digitalizing Russia. The uneven pace of progress towards ICT equality. In: Ragnedda, M., \& Muschert, G. W. The Digital Divide: The Internet and Social Inequality in International Perspective. Routledge.

GENDINA, N., KOLKOVA, N., STARODUBOVA, G., ULENKO, U. (2006). Formirovanie Informacionnoj Kul'tury Lichnosti: Teoreticheskoe Obosnovanie i Modelirovanie Soderzhaniya Uchebnoj Discipliny [Formation of the Information Culture of the Individual: Theoretical Justification and Modeling of the Content of the Academic Discipline]. Interregional center for library cooperation.

GLADKOVA, A., GARIFULLIN, V., \& RAGNEDDA, M. (2019). Model tryokh urovnei tsifrovogo neravenstva: sovremennye vozmozhnosti i ogranicheniya (naprimere issledovaniya Respubliki Tatarstan) [Model of the three levels of the digital divide: Current opportunities and limitations (exemplified by the Republic of Tatarstan)]. Vestnik Moskovskogo Universiteta. Seriya 10. Zhurnalistika 4, pp. 41-72. 
GLADKOVA, A., \& RAGNEDDA, M. (2020). Exploring digital inequalities in Russia: an interregional comparative analysis. Online Information Review, 44(4), pp. 767-786.

GLADKOVA, A., VARTANOVA, E., \& RAGNEDDA, M. (2020). Digital divide and digital capital in multiethnic Russian society. Journal of Multicultural Discourses, 15(2), 126-147. DOI: 10.1080/17447143.2020.1745212

GOGGIN, G., ELLIS, K. \& WAYNE, H. (2019). Disability at the centre of digital inclusion: assessing a new moment in technology and rights. Communication Research and Practice, 5:3, pp. 290-303.

HAMELINK, C. (1976). 'An alternative to news', Journal of Communication 26, $122 \mathrm{p}$.

HARGITTAI, E. (2002). Second level digital divide: differences in people's online skills. First Monday, 7(4). Available from: https://firstmonday.org/article/ view/942/864

HOUK A., BOGART C. (1974). Media Literacy: Thinking About. Dayton, Ohio: Pflaum/Standart.

KELLNER, D. (2001). New technologies/new literacies: reconstructing education for the new millennium. International Journal of Technology and Design Education, 11, pp. 67-81.

KOLOMAK, E. (2010). Mezhregionalnoe neravenstvo v Rossii: ekonomicheski i isotsialniy aspekty [Interregional inequality in Russia: economic and social aspects]. Prostranstvennaya Ekonomika, 1, pp. 26-35.

KRESS, G. (2003). Literacy in the New Media Age. Routledge. - 208 p.

LAPIN, D. (2020). Mediaobrazovanie shkol'nikov v Rossii: ot protoformatov $\mathrm{k}$ konsensusnomu podhodu [Media education of schoolchildren in Russia: from proto-formats to a consensus approach] // MediaAlmanah: 6.

LITERAT, I. (2014). Measuring new media literacies: Towards the development of a comprehensive assessment tool. Journal of Media Literacy Education, 6(1), pp. 15-27.

LIVINGSTONE S. (2004). Media literacy and the challenge of new information and communication technologies. The Communication Review 7(1). DOI: $10.1080 / 10714420490280152$

LIVINGSTONE, S., \& HELSPER, E. (2010). Balancing opportunities and risks in teenagers' use of the internet: The role of online skills and internet self-efficacy. New Media \& Society, 12(2), pp. 309-329.

MARTIN, A. (2006) Digital literacies for learning. Journal of Information Literacy, 1(3). 
MCLUHAN M. (2018). Ponimaniye Media. Vneshniye Rasshireniya Cheloveka [Understanding Media: The Extensions Of Man]. Kuchkovo polye publ.

MURATOVA N., GRIZZLE A., MIRZAKHMEDOVA D. (2019). Media and Information Literacy in Journalism: A Handbook for Journalists and Journalism Educators. Tashkent: Baktria Press. -128 p.

MIKHEEVA, L. (2004). Faktory neravenstva dostupa k vyshemu obrazovaniu v sovremennuh usloviyah Rossii [Factors of unequal access to the higher education in modern Russia]. Izvestiya Vyshyh Uchebnyh Zavedenii, 3, pp. 126-130.

Ot Teorii Zhurnalistiki $k$ Teorii Media. Dinamika Mediaissledovanij $v$ Sovremennoj Rossii [From the Theory of Journalism to the Theory of Media. Dynamics of Media Research in Modern Russia]/ed. Vartanova, E. MSU Press Publ.

OWENS, M. (1976). State, Government and Libraries. Library Journal 101, - 2 p.

RAGNEDDA, M. (2018). Conceptualizing digital capital. Telematics and Informatics, 35, pp. 2366-2375.

RAGNEDDA, M., \& KREITEM, H. (2018). The three levels of digital divide in East EU countries. World of Media. Journal of Russian Media and Journalism Studies, 4, pp. 5-27.

RAGNEDDA, M., RUIU, M., ADDEO, F. (2019). Measuring digital capital: An empirical investigation. New Media \& Society, 1, pp. 1-24.

SHARIKOV, A. (2013). V poiskah obshchego metodologicheskogo bazisa teorij mediaobrazovaniya i informacionnoj gramotnosti [In search of a common methodological basis for the theories of media education and information literacy]. Media i Informacionnaya Gramotnost'v Obshchestvah Znaniya. M.: MCBS.

The Digital Divide. The Internet and Social Inequality in International Perspective / ed. Ragnedda, M., Muschert G. New York : Routledge, 2013. - 344 p.

VAN DEURSEN, A., HELSPER, E. (2015). A nuanced understanding of Internet use and non-use among the elderly. European Journal of Communication, 30(2), pp. 171-187.

VAN DEURSEN, A., \& VAN DIJK, J. (2014). The digital divide shifts to differences in usage. New Media \& Society, 16(3), pp. 507-526.

VAN DEURSEN, A. J., \& VAN DIJK, J. A. (2018). The first-level digital divide shifts from inequalities in physical access to inequalities in material access. New Media \& Society, 21(2), pp. 354-375.

VAN DIJK, J.A. (2013). A Theory of the Digital Divide / J.A.G.M. van Dijk // The Digital Divide: The Internet and Social Inequality in International Perspective / ed. Ragnedda, M., Muschert, G. New York : Routledge, pp. 28-51.

VAN DIJK, J. A., \& HACKER, K. (2003). The digital divide as a complex and dynamic phenomenon. The Information Society, 19(4), pp. 315-326. 
VARTANOVA, E. (2002). Digital divide and the changing political and media environment of post-Socialist Europe. Gazette 5(64), pp. 449-465.

VARTANOVA, E. (2009). De-Sovietizing Russian media studies. In: D. K. Thussu (ed.), Internationalizing Media Studies pp. 214-227. NY: Routledge.

VARTANOVA, E. (2018). Kontseptualizatsiya tsifrovogo neravenstva: osnovnye etapy [Conceptualizing digital divide: Main stages]. MediaAlmanah, 5, pp. 8-12.

VARTANOVA, E., GLADKOVA, A. (2019). New forms of the digital divide / In J. Trappel (ed.) Digital Media Inequalities: Policies against Divides, Distrust and Discrimination. Goteborg: Nordicom, pp. 191-211.

VOLCHENKO, O. (2016). Dinamika tsifrovogo neravenstva v Rossii [Dynamics of the digital divide in Russia]. Monitoring Obshchestvennogo Mneniya, 5, pp. 163182.

WAKS, L. (2006). Rethinking technological literacy for the global network era. In: Defining Technological Literacy, pp. 275-295. DOI: 10.1057/9781403983053_18 